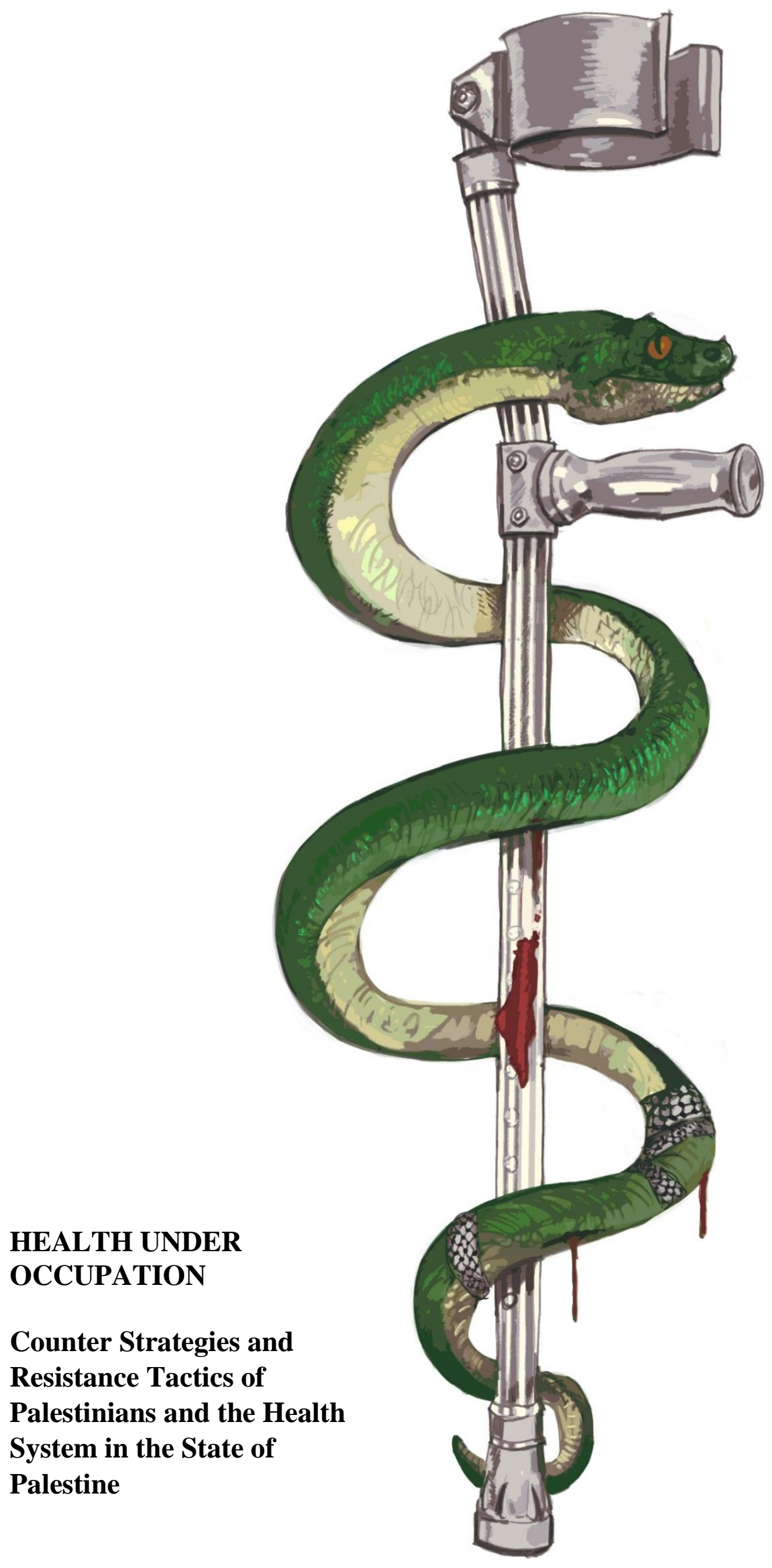

SIGGE ANDERSSON

DEGREE PROJECT IN MEDICINE 


\section{THE SAHLGRENSKA ACADEMY}

Health under Occupation

Counter Strategies and Resistance Tactics of Palestinians and the Health System in the State of Palestine

Degree Project in Medicine

Sigge Andersson

Programme in Medicine

Gothenburg, Sweden 2018

Supervisor: Gunnar Olofsson, MD, PhD

Surgery \& Ear Clinic, Södra Älvsborg Hospital 


\section{Populärvetenskaplig sammanfattning på svenska}

I Palestina påverkas det dagliga livet av förhållanden som har med den israeliska ockupationen att göra. Syftet med föreliggande studie är att undersöka hur ockupationen av Palestina påverkar hälsa och tillgång till hälso- och sjukvård. Huvudförfattaren har besökt olika samhällen i Jerusalem och Västbanken för att samla in källuppgifter. Studien utgörs av en analys främst av intervjuer med palestinier yrkesverksamma inom hälso- och sjukvården samt av anteckningar från fältarbete i landet. Författaren analyserar och undersöker olika konsekvenser av ockupationen som förmodas påverka palestiniers livskvalitet och tillgång till sjukvård.

I resultaten framgår att isolering är ett av de fenomen som verkar ha stor påverkan på hälsa och tillgång till hälso- och sjukvård i Palestina. Isolering skapas av ett flertal olika barriärer bland annat muren, vägspärrar och bosättningar. I en enkätundersökning där även skattningsskalor för livskvalitet och hälsobeteende användes tillfrågades ett hundratal universitetsstudenter om huruvida de var drabbade av olika faktorer relaterade till ockupationen. Drygt hälften påverkades i sin vardag av vägspärrar, muren samt genom att ha fängslade eller dödade anhöriga, dock utan tydligt samband på uppmätt livskvalitet. I arbetet undersöks hur barriärer har påverkan på människors liv och hälsa, framför allt i termer av livskvalitet på bas av möjligheter att arbeta, studera och upprätthålla sociala nätverk. En av studiens slutsatser är att isoleringen påverkar tillgång till sjukvård negativt.

Barriärer har bidragit till framväxten av strategier och taktiker för att hantera vardagen under ockupation. Hos de som intervjuas tas initiativ på det personliga såväl som samhälleliga planet upp som exempel. I en diskussionsdel relateras studiens resultat till andra studier och det föreslås fortsatt forskning om hur människor hanterar konflikter och trauma. 


\section{Innehåll}

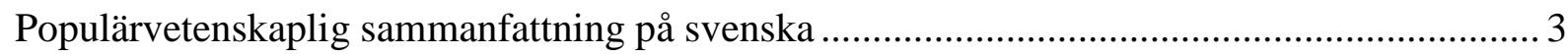

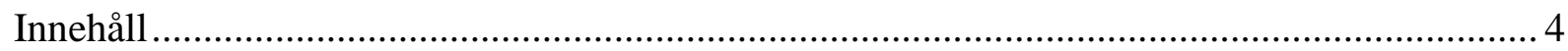

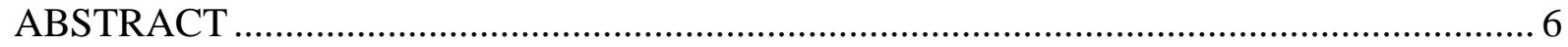

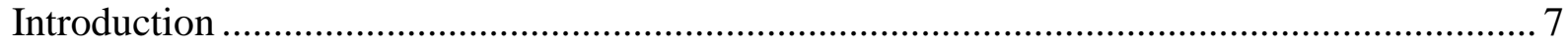

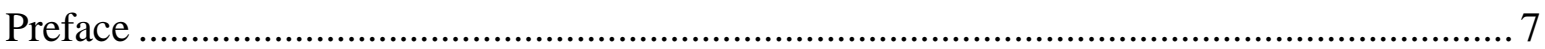

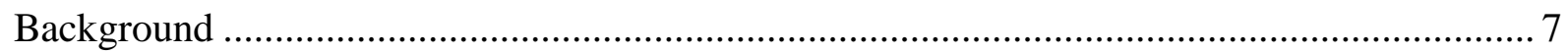

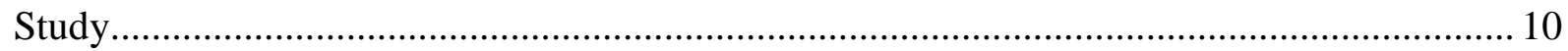

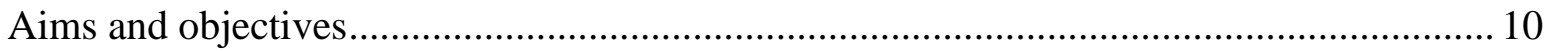

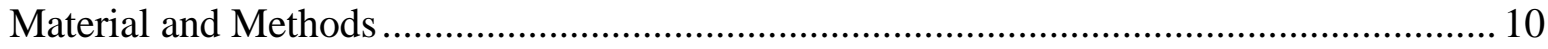

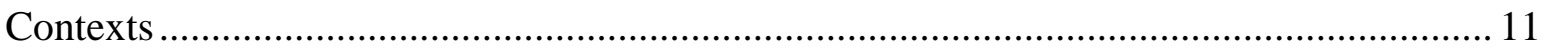

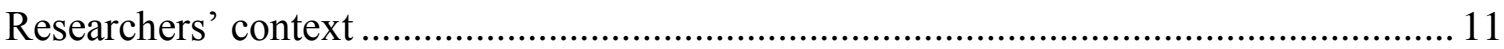

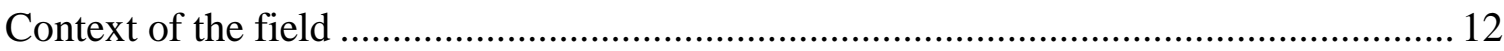

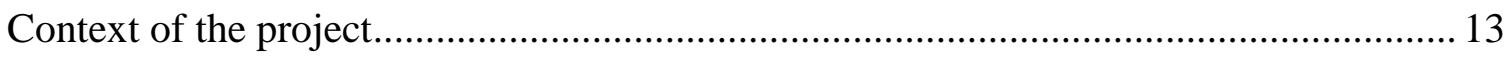

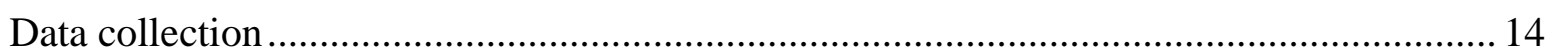

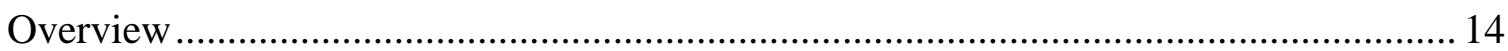

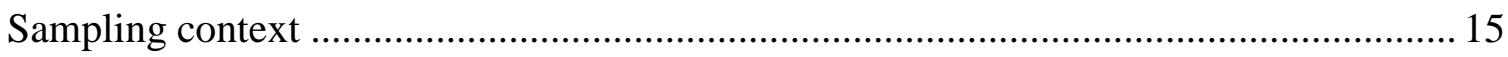

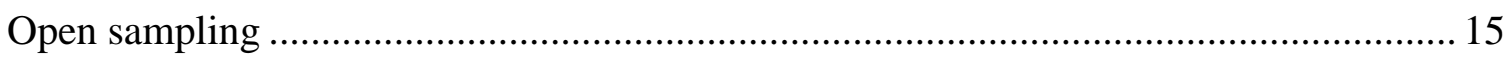

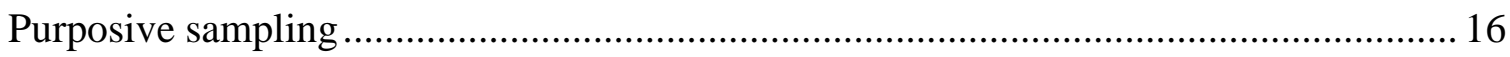

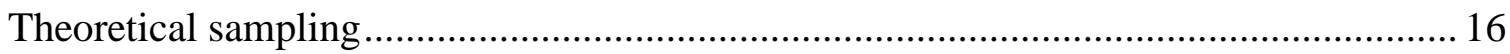

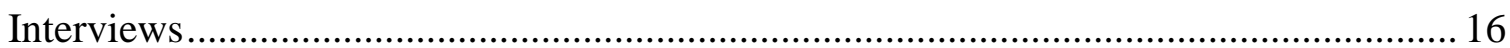

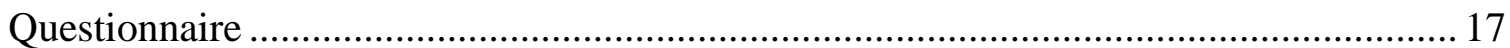


Memoing.....

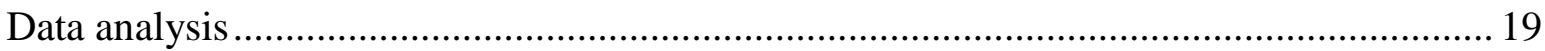

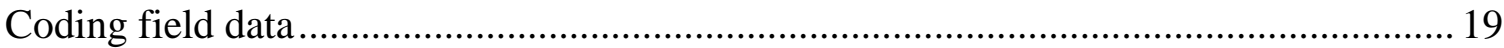

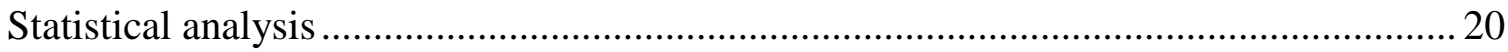

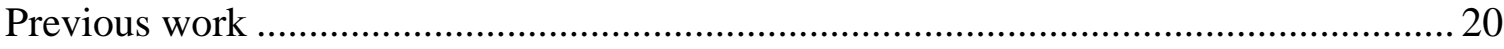

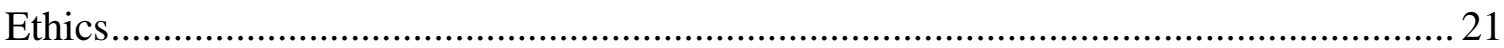

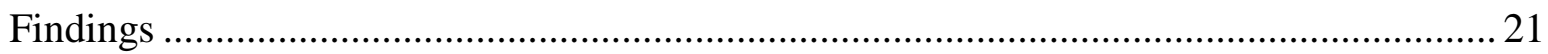

A theory on isolation under occupation and everyday strategies.................................. 21

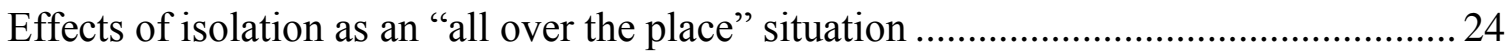

Occupation as apparent in everyday life and its determinants of health......................... 26

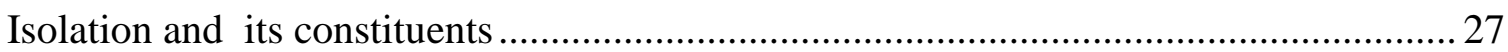

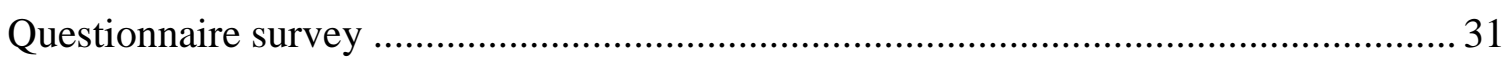

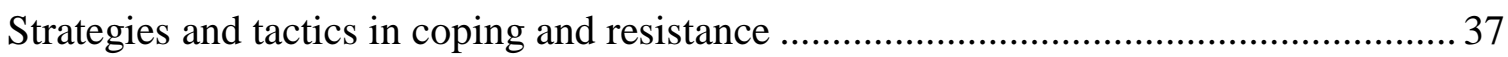

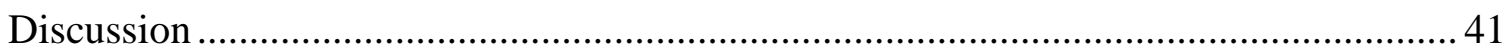

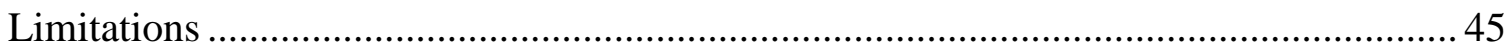

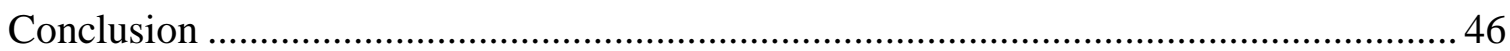

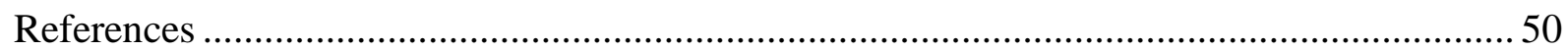

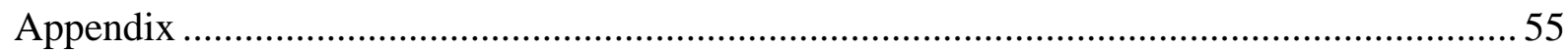




\begin{abstract}
The impact of occupation on health and access to health care is a significant issue for the state, health sector and citizens of Palestine, who struggle with difficulties related to an enduring sociopolitical stalemate.
\end{abstract}

The study presents narratives from the field, conceptually exploring if and how occupation affects health and access to health care and how the situation is tackled by Palestinians in general and by health system actors specifically. A grounded theory approach analyzing indepth interviews with health staff and field memos was used, with semi-quantification of emerging concepts through surveys of Hebron students that assessed health-related quality of life and health literacy with psychometric instruments (SF36 and GSE) and assumed health determinants.

One key theme in the data analysis was isolation as a result of multiple barriers, including the wall and checkpoints, imprisonment and violence, which have an impact on determinants of health and quality of life in Palestine. In the survey 54\% $(n=90)$ were affected by such factors of occupation. Barriers affect access to health care, especially in rural areas. Mentally and materially breaking free from barriers of occupation seems to be a common task in all levels of Palestinian society. Achieving this goal requires different counter strategies and tactics. Presently, Palestine depends on ad hoc coping strategies, including the use of mobile clinics. Other ways to cope emerged in the data as well.

Results from this mixed-methods study suggest that isolation is a main concern for Palestinians, resulting from barriers in policies of occupation that affect health and access to health care. Another concept emerging from the analysis was tactics and strategies against occupation in society.

KEY WORDS: State of Palestine, Occupation, Strategies, Health System, Resistance 


\section{Introduction}

\section{Preface}

This study aims to explore how Palestine and Palestinians are affected by occupation in health-related matters in everyday life. The field project was conducted over three months in the field, in Jerusalem and the West Bank. Most of the data were collected inductively, and results are to be viewed more as an exploration of the field than an exact account. The authors have extensive experience with the Palestinian question, and the purpose of the study is not present a balance of views on the Israeli-Palestinian conflict. Hopefully, this study contributes to understanding how people and their health are affected by problematic political realities and how they cope with their situations.

\section{Background}

Palestine is a country of 4.4 million inhabitants. Public health data from the Palestinian Central Bureau of Statistics (PCBS) suggest that the country's health is comparable to that of neighboring Arab countries, with high immunization coverage and a high percentage of women (> 95\%) receiving antenatal care and giving birth in health institutions. The differences within the country are significant; infants born in the richest $20 \%$ of West Bank and East Jerusalem populations are approximately twice as likely to survive their first year compared to infants born in Gaza. The panorama of non-communicable disease illustrates an epidemiological transition; non-communicable diseases are now the main cause of mortality, with a considerable increase in mental health patients (Mataria et al., 2009; PCBS, 2004, 2013).

The health system era in Palestine has had four chapters in the past century: from the 1920s, it was led by the Department of Health under British civil administration during colonial rule over the Palestine mandate. From 1948, after the creation of State of Israel, the health system 
was under the rule of Egypt in Gaza and of Jordan in the West Bank; both of these ministries were called the Ministry of Health. After 1967, the Palestinian health system was under the rule of the Israeli Defense Forces (IDF) and neglected. Health services were provided by the occupants and by humanitarian aid and professional organizations associated with different factions of Palestinian politics. In 1994, after the Oslo Peace Accords, the Palestinian Authority (PA) was created along with the current Ministry of Health; these institutions, with non-governmental organizations (NGO) and private sector, constitute the Palestinian health care system, with internal refugees cared for by the United Nations Relief and Works Agency for Palestine Refugees in the Near East (UNRWA). The physical separation between the localities under PA administration, Gaza and the West Bank, has in recent years been constrained by the Hamas-Fateh split, followed by the coup against Hamas after its' victory in the democratic elections 2007 (R. Giacaman, 2003; Olofsson \& Österholm, 2016).

The PA has even less control over the determinants of water, land, environment and movement under the current occupation. This is not ideal for a public health approach to health system development. The structural and political conditions of Palestine are the key determinants of population health, which is why Western foreign policy focused on aid policies have been criticized for not addressing the root cause of occupation, even if aid has short-term effects in Palestine's socio-economic crisis. (Rita Giacaman et al., 2009). The Palestinian NGO Network (PNGO) consists of several NGOs, including the Palestinian Red Crescent Society (PRCS) and "popular committees" built up by leftist factions of the Palestinian nationalist liberation movement, Palestine Liberation Organization (PLO). Today, the NGOs establish nominally independent organizations and comprise a large share of the primary health care, especially in remote areas. Other health organizations and social service providers include the Islamic Zakat committees, international aid organizations and local community-based organizations (Challand, 2009). The UNRWA is formally obligated by UN 
to provide for the 2 million internal and 2.9 million external refugees (Ewen, Sakit, Saadeh, Vialle-Valentin, \& Seita, 2012).

The socio-economic situation has worsened since the second Intifada. In 1999, the unemployment rate in Palestine was 12\%; in 2012, it was $19 \%$ in the West Bank and $31 \%$ in Gaza. Poverty has similarly risen from $28 \%$ in 1999 to $40 \%$ in the West Bank and $74 \%$ in Gaza by 2007. One determinant that has improved is education; the high literacy rate is comparable to Western standards. However, other determinants such as food security and water supply are deteriorating, with 54\% of the population in Gaza experiencing food insecurity and more than $75 \%$ dependent on aid. Ninety percent of the water resources in Palestine are controlled by Mekorot, a company owned by the Israeli military, and $95 \%$ of the water volume pumped for human consumption in Gaza is polluted and unfit for drinking. The Palestinian Water Authority estimates that almost $40 \%$ of the incidence of disease in Gaza is related to polluted drinking water and that $20 \%$ of Gazan families have at least one child under the age of five who suffers from diarrhea because of water pollution, and UN studies suggest that polluted water is the cause of $12 \%$ of children's death in the region (Haavisto, 2010; PCBS, 2012; Selby, 2002).

Childhood development and childhood health are affected by food insecurity. Stunting is increasing, and the rate of anemia is high. The "chronic" state of conflict is debated as a cause of aggressive behavior among boys. Post-traumatic stress disorder (PTSD), depression and severe anxiety symptoms are seen in $69 \%, 40 \%$ and $95 \%$ of Gaza adolescents, respectively. Children are subjects of Israeli detention by Israeli Defense Forces (IDF), often without any formal charge, and are kept away from their families and exposed to interrogation techniques defined as torture by UN declarations. From 2007-2011, between 221 and 450 children were in detention each month (DC International/Palestine, 2011; Massad et al., 2012; Neria, Besser, Kiper, \& Westphal, 2010). In a study of children's symptoms in the wake of the first Intifada, 
Baker (1991) found correlations between the symptoms and environmental stress and violence exposure under the occupation, suggesting that events related to the occupation are relevant determinants of mental health.

While the determinants of health and political conflict in Palestine is a theme in several works on Palestine, conceptual research on effects of occupation as experienced by common Palestinians and health workers is scarce. Research on health status of Palestinians and the health system has suggested that approaches are often particularistic, addressing somatic disease and separating determinants from a crisis, the effects of which are poorly understood. The state of existing research creates a rationale for a more conceptual analysis of the current situation and its implications for health in Palestine to explore issues of significance for people in the country.

\section{Study}

\section{Aims and objectives}

The aim of this study is to explore whether and how the current occupation of the state of Palestine by a foreign power affects health and access to health care in Palestine. The objective is to study how occupation affects health in Palestine, with a conceptual framework rooted in the philosophical current of pragmatism that enables exploration of Palestinian reality.

\section{Material and Methods}

To form the conceptual framework of this study, we used a qualitative method of conceptualization with a grounded theory approach, in which deep interviews with health staff were the main data source, supplemented by memos from the field in combination with semi- 
quantification of initially emerging concepts based on the quantitative data from a questionnaire survey.

This work uses a Grounded Theory (GT) approach, with applications primarily developed from the works of Glaser $(1992,2004)$ and Strauss (1987), the seminal founders of GT. Grounded theory allows the researcher to explore reality in an inductive-deductive process in which the conceptualization is grounded by a continuous and simultaneous process of analyzing and sampling. Additional concepts have been borrowed from GT researchers Clarke, Friese, and Washburn (2015). Grounded theory is a pragmatist methodology, here used within a conceptual framework of symbolic interactionism. As argued by Blumer (1969), "human beings act towards things on basis of the meaning the things have to them," which is the root assumption of symbolic interactionism according to Lindesmith, Strauss, and Denzin (1999). The meanings arise from reflection and social interaction between people and their reflexive minds, allowing humans to make interpretations and to change the meanings of things. We chose a GT approach to examine events in the field, understand what matters to actors in various categories and explore relations in people's social reality that are relevant to the study's purpose.

\section{Contexts}

\section{Researchers' context}

We have been engaged in the situations that created the data of the study, not only by taking part in and being affected by the participants and situations observed, but also by making our own impacts. This engagement is in accordance with the conceptual framework of symbolic interactionism and the author's view of scientific research as a human activity. The researchers' impact on the situation has been minimized as much as possible by the design of the method. This work is empirical and qualitative in nature, applying mixed methods with a grounded theory approach. This approach, along with the use of reflection as an important 
instrument of analysis, couples the findings to our personal understanding of life, society and Palestine, of which we will try to give an account.

The primary researcher works as an assistant physician and is a medical student with a background of activity in democratic organizations such as workers' unions, movements for social action and youth leagues since childhood. These organizations include networks for the development and support of the State of Palestine, but the primary researcher had no formal membership in any organizations of this kind during the research process. The supervisor has a $\mathrm{PhD}$ in urology and field experience from Palestine and the West Bank from several factfinding missions for international NGOs and from working as a medical doctor in Palestine and Palestinian refugee communities in neighboring countries.

From visiting most parts of North African and West Asian Arab countries both privately and for work, we have an existing understanding of some of the cultural framework and habits and can recognize attitudes of common Arab sentiments toward Israeli policies, which are reflected in the text. This prior understanding makes the research a combination of a rerepresentation of common perceptions in the "Arab Street" and the researchers' own understanding based on their own experiences as Swedish nationals who are inherently a part of Swedish culture. Our Swedish society's cultural rootedness and commitment to concepts such as general welfare with worker's rights, "folkhemmet" and laws stipulated by the common people as a foundation for democratic society has also helped us become dedicated to and educated in human rights as presented by the UN General Assembly in its 1949 declaration and in the Human Rights Act of 1793.

\section{Context of the field}

The study was carried out in the governorates of Jerusalem, Ramallah, Salfit, Nablus, Qalqilya, Tulkarm, Hebron and Bethlehem. The research in Palestine was based in Bethlehem at the office of Golden Gate Tours at Manger Road. The PNGO members Health Work 
Committees (HWC), Union of Health Care Committees (UHCC) and Palestinian Medical Relief Society (PMRS) facilitated the research process.

The HWC, UHCC and PMRS are health-care oriented former "popular committees" and offshoots of PLO factions, established during the decade after the Israeli Occupation with the task of supplying its creators and funders. Developing from factionalist to nominally independent NGOs with services for all has been a process that was partly made possible through international aid from European and Gulf countries. Today, their dependence on local political powers varies, but they are dependent on foreign aid (Beinin \& Stein, 2006; Hammami, 2000).

These organizations also provided a steady supply of contacts and sources of information, particularly access to health care facilities and professionals interviewed as key informants. While we met people of many dissimilar categories from the Palestinian societal strata, a significant majority of study participants was comprised university students, intellectuals, graduates or skilled laborers - folks of higher education and higher socio-economic status. Using snowball sampling with the contacts allowed for further social and scientific exploration, sometimes performed in overlap, with visits to families, other organizations, meetings and situations. When an idea or concept struck us in these situations, it was recorded as soon as possible. The field experience made an impression, adding many layers over the understanding of the situation and its context(s).

\section{Context of the project}

Since 2000 and the Al Aqsa Intifada in Palestine, the arena of Palestinian health care has changed along with the transformation of Israeli occupation (Rita Giacaman et al., 2009). This project aims to answer how, why and who benefits from this transformation and what will happen next. The study was conducted as a part of the Swedish Physician Education's Exam project, within the framework of Global Health, which was studied in a course preceding the 
project. The project was planned by the author and supervisor. The supervisor is a Swedish $\mathrm{MD}$ and $\mathrm{PhD}$ with broad experience in international work, especially in Palestine. In Palestine, the initial phase of the project was carried out under additional supervision by a Palestinian MD and PhD. Because the Palestinian supervisor was appointed the Health Minister of the Ministry of Health of the State of Palestine on 16 May 2012, when the project was in its nascent stage, most of the project was carried out with help from supervision in the field. This supervision was organized by the primary researcher's own initiatives to obtain counsel from informed sources, health professionals and academicians, especially within the field of public health, at Al Quds University, Bir Zeit University and Ramallah Office of Health Work Committees.

\section{Data collection}

\section{Overview}

Field data was collected in Jerusalem and the West Bank, State of Palestine, from April to July 2012. Data was collected primarily by the author and colleagues. The data collection was carried out using sampling techniques in GT (Glaser, 2004). Data includes memos and 11 in depth interviews held with health staff in Jerusalem, Ramallah, Hebron, Bethlehem, Salfit and Qalqilya districts. Memos from participant observations, theoretical memos written during the research process and artefacts from the field are also included. A questionnaire survey, consisting of sociodemographic determinants as well as exposure to factors of occupation, was used along with psychometric instruments assessing health-related quality of life (Short Form 36 [SF36]) and health literacy (General Self Efficacy Scale [GSE]) among the sample of university students, with the results regarding the occupation semi-quantified. Two literature reviews were carried out, an initial to "nest up" the question of Palestine before the project field study, and a second after data sampling and slightly into the coding process, for additional theoretical sampling, corroboration and to add richness to data (Glaser 2004). 


\section{Sampling context}

The field project that is the foundation for the thesis was carried out in Jerusalem and West Bank 2012. It began upon arrival with participant observation in temporal situations such as demonstrations and visits to Palestinian families of different social and economic classes, university faculties and geographic sites of interest for the study. Initial open sampling was used to obtain a maximum variety of data of possible interest and use for the research objectives. With the help of the International Federation of Medical Student Associations Palestine (IFMSA-P) and the Nidal Center of HWC in the Old City of Jerusalem, snowballing generated contacts with different organizations and these contacts developed into a program, which was carried out with modifications based on methodological considerations.

\section{Open sampling}

During this phase of the study, several municipalities, towns, sites and organizations were visited. Glaser (2004) suggests that a grounded theory study begins with open sampling and asking the field, "What is happening here?" to explore what is important to common people participating in it.

Palestine is an Arab country and is therefore hospitable to peaceful visitors. Consequently, the author had the privilege of befriending many Palestinian families over tea or dinner, not only for formal reasons but simply through moving around and meeting people in the city and in public places.

For an exchange student, these invitations were helpful opportunities to get to know more about the country of visit, its customs and topics of interest in the lives of its people. Some of these occasions gave the opportunity to discuss with key informants on the meso-level. In a study using the grounded theory approach, these occasions are useful for the corroboration of collected data and can give clues to and validate emerging theory, a function that is both a limitation and a strength. 


\section{Purposive sampling}

When a wide range of indicators of interesting categories had been collected and the same indicators began to recur in the material collected, we decided to narrow the sampling focus and use a purposive sampling.

The purposive sampling was carried out to verify and add generalizability to coded data, based on the presumption that geography as a variable of occupation could be of importance in further research. Additional health staff personnel were supposed to be key informants on the research topic, so the sampling was carried out among health service staff in NGOs throughout the governorates of West Bank.

\section{Theoretical sampling}

After purposive sampling, theoretical sampling regarding the choice of interviewees was used, this time with two senior officials in two different health NGOs. They were viewed as credible key informants, and during interviews, we asked about emerging concepts in the study to discover new perspectives and angles to the data for theorizing. Our theoretical sampling also included collecting of artefacts and a second literature review at the end of research, this time focusing on adding richness to data and corroboration.

\section{Interviews}

In interviews conducted by the author, categories began to take form. Participants were framed face-to-face at their work places, informed by their employers in advance. Participants were based in various localities throughout the West Bank, primarily consisting of physicians of both sexes but mostly men. Initially, interviews were recorded, based on the recommendations of Strauss \& Corbin (1990), but the question is also discussed briefly by Glaser (2004), who recommends notes as the primary technique. After three interviews, it appeared to us that recording, particularly using a cell phone the first time and later a Dictaphone, created nuisance for the participant. When one of the participants asked us to turn 
off the device due to sensitivity of the data discussed, referring to security reasons, the practice was changed to note-taking only while interviewing, with the interview closed after rechecking the data with the interviewee. Interviews were written out fair using a word processor the same evening.

In the initial process of purposive sampling, we had four category indicators that we treated as possible core categories for topics in an interview guide. After two interviews, it was apparent that one of the core categories discussed as a theme in the guide did not fit the interviewees' narratives about why the interview guide was changed. The interviews lasted 35 to 90 minutes, with the variation mostly due to restricted time or disturbances. A typical interview lasted for 50 minutes.

\section{Questionnaire}

Based on emerging concepts in field studies, we distributed a questionnaire to 105 students of Hebron University with the motive of exploring to what extent and in what ways eminent factors of Occupation were apparent in the students' lives, and if they related to quality of life or health literacy as depicted by the psychometric instruments. Initially, the plan was to use a clustered random sample based on the university student roll, while the resulting survey made up a convenience sample for feasibility purposes. Its design, administration and time for its distribution were approved by university officials. The questionnaire was designed to include determinants of health represented by basic socio-demographic data, including socioeconomic stressors and exposure to factors of Occupation, which has emerged in data analysis so far. The selected population was of interest due to its relation to factors of Occupation, such as the geographical location. The interviews were based in Hebron, where settlers, soldiers, curfews, violence as well as wall and checkpoints are a part of everyday-life, as judged from reports provided by the Office for Coordination of Human Affairs Occupied Palestinian territories and information from the field. The questionnaire was based on three 
items: the SF-36, the General Self Efficacy scale and the socio-demographic questionnaire, including exposure of assumed relevant factors of Occupation in everyday life. Validated Arab language versions of Optum's SF-36 (licensed) and GSE were used. The last form including determinants and factors of occupation was designed by the main author and an administrator of an international NGO who spoke Arab as her mother tongue and formal English as her working language, and a back-translation to English was made by a scout and a student panel of four students, confirming its validity and cultural sensibility. A pretest pilot was carried out in another two students. The questionnaire was administered to students by a scout employed by the university who was familiar with the students but did not have other bonds of dependence, informing students of the purpose of the questionnaire and confirming the informed consent of those surveyed. Students were filling out the forms individually, although sitting at tables allowed for pairing of days 1 and 2. This was avoided the other day by rearranging the furniture in the rooms used. Any of the three items consisting of more than 90\% answers were included in analysis. After the participants had filled out the forms, the scout collected the questionnaire from each student individually.

\section{Memoing}

During all research processes, especially coding, memos must be written to stay alert, keep theoretical sensitivity in the research process and explore "latent" data. Included in memos were references to artefacts, such as cultural events, art and posters. Memoing, carried out through participant observation in the field, is a key analytic instrument for generation of concepts. In memoing, we have used techniques described by Clarke (2015) designed for GT, including the "mapping" of situations by creating lists over "actors" in the field, emerging concepts and narratives and exploring how they relate. Glaser does not approve of such techniques, claiming that they "force" theory out of the data, while Strauss and Corbin do approve if the method is accounted for. Mapping has been used when ordinary "sorting" of 
category indicators has not generated the emerging conceptualization. Even if we primarily used Glaser's approach to general GT topics, we disagree with Glaser (2004) on his rigidity in considering conceptualization with tools as the forcing of data.

\section{Data analysis}

\section{Coding field data}

Coding was carried out by looking for and highlighting indicators of categories in data, initially running the data "open", writing analytical memos, looking for "latent" category indicators in descriptive memos and coding artefacts with labels of possible category indicators. Indicators that fit together were sorted in categories. The aim of these actions was to look for as many indicators of categories as possible to reach "data satiety" or at least maximum possible variation. In sorting the category indicators, there was an exploration of how emerging categories related to each other, writing memos on their relations.

Memoing was facilitated by ideas created through the constant comparative method, in which the data was compared continuously, with consideration of category indicators, categories and the later emerging core categories. Comparing categories delimited them, and flaws in sorting and indicators that did not belong were noticed. Data that did not fit in a category was either sorted into another category when applicable or prompted us to reflect on whether the category it belonged to needed redefinition. In a few cases, the data was removed as a negative example; it was either left out from further analysis, analyzed once more with a changing of its original category or sorted in a new stack of codes to constitute a completely new category, depending on where in the coding process the event took place.

We carried out analysis of data from the first day in the field. Initially, only memo-writing was used, together with the collection of artefacts while visiting organizations in the open sampling phase. When purposive sampling took place, data in the form of semi-structured 
interviews became available. Initially, the interviews were coded openly line-by-line as described by Glaser (2004), highlighting incidents in the data as category indicators and either labeling them or using them as "in vivo" codes. A handful core categories, under which the other categories were sorted, emerged after only one interview. Along with the theoretical sampling that took place during that phase, the coding process changed to selective coding, in which the process was focused on analyzing indicators sorting under the core categories and their relations. This phase spurred memoing as a way to summarize conclusions and thoughts on the data. Selective coding was also used when analyzing data acquired by theoretical sampling.

\section{Statistical analysis}

Descriptive statistical analysis of questionnaire data from the Hebron University survey was conducted using $\mathrm{R}$ for graphical comparison across samples with boxplots. In the findings, the properties are explained further in each boxplot picture legend. Statistical analysis was conducted for "semi-quantification" of emerging concepts in the GT process.

\section{Previous work}

In 2008, three young doctors and a pre-medical school student (the author) visited Palestine in an exchange program between research teams in the pharmacological institutions of the medical faculties of Al Quds University in East Jerusalem and Gothenburg University. The field notes were based primarily on participant observation, transcribed daily every evening in a diary. The field notes for this trip were edited and published upon arrival back home in Sweden by the Memorial Foundation of Olof Palme, which also financed the exchange project (see Andersson, Pehrsson, and Fridlund [2008]). This work captured the preconceptions of the head author, which influenced the initial research process and open sampling in current research. Further relation between the head author and two of the NGOs who assisted in carrying out the research project was already established during this first field 
study. The work was used in theoretical sampling, as cited in the discussion in which conceptual connotation with categories was identified.

\section{Ethics}

The study as carried out in accordance to the Helsinki Declaration and with a goal of observing UNESCO's Code of Conduct for Social Science research. Informants, participants and respondents were informed of the purpose of this study and asked to give their informed consent when contributing to it actively. This was not the case when writing memos in official places or when witnessing incidents reported, but in such cases, anonymization has been utterly strict. With safety in mind, all personal data of individuals have been anonymized. Permission has been granted from employers to conduct the study at universities and NGOs. Interviewees were informed that their participation in all phases was contingent on their consent and made aware beforehand that they could stop whenever they wanted to. Where applicable and practically possible, results of the study were shared with informants. Data have been stored in such a way that no third parties have had access to it.

\section{Findings}

\section{A theory on isolation under occupation and everyday strategies}

The aim of this study is to explore whether and how the current situation in Palestine, as a state occupied by a foreign power, affects health and the health system in Palestine. An objective is to give an account of the many ways Palestinians and their health system cope with limited territorial integrity in regards to health, access to health care and determinants of health. A grounded theory approach is used to fulfill this purpose by evaluating data from key informants and participant observation, conceptualizing basic social processes in emerging category indicators assisted by memoing conducted in parallel with interviews and using a constant comparative method in analysis. 
In the generated theory, isolation is the phenomenon constituting the core category. The context of isolation is occupied Palestine, in which various barriers created by the occupation power constitutes causal conditions creating the phenomena. Isolation is a core category grounded in data and field work; it and its determinants affects health-related quality of life.

The architecture of isolation consists of a set of barriers, including but not limited to military checkpoints, Israeli-exclusive settler roads cutting off and dividing Palestinian geographical areas, land-trapping through military delineation and the wall (also known as the separation barrier in Israeli discourse).

Barriers are not just physical, but also abstract; they can include fear of violence, such as raids in camps and settler violence. For the individual, loss of opportunities is a category of significance, acting as a barrier in the search for self-efficacy and empowerment. Administrative barriers consist of an extensive system of different obligate permits for all kinds of transport and trade; these are another obstacle with effects not least on an institutional level, including organizations within the health sector.

Data suggest that the occupation is "all over the place", and an interviewee described it as "affecting everything". This view contributed to the principal standpoint in analysis, in which the effects of the occupation on the general population were indicated recurrently during coding while narratives of pathologizing were avoided. In analysis, this standpoint helped exclude a pathologizing narration of a political situation, to avoid suggestions of erroneous biomedical solutions to societal problems. Instead, a wider focus incorporating determinants of health was used to conceptualize main predictors of individual health, as well as the concept of quality of life, to approach health issues more broadly. Indicators in data suggested that the main determinants of health included work, area, gender, socio-economic status (SES), education and familial relations. Even if the occupation was "all over the place", there are group biases, considering the youth in socio-economically weaker groups in refugee 
camps who are victims of the harshest violence in recurrent military raids, or female children who are married away in early ages under economic hardship.

Barriers of isolation under occupation have far-flung consequences, where daily movement restrictions, restrained social networking, limited chances for leisure travel and transport difficulties appear among the most significant. Altogether, these transportation barriers create a sense of loss of control in the individual and society in Palestine and contribute to frustration among its citizens and society. Several informants describe severe stress due to the situation; this is also true for the general population, as stress is assumed to have a negative effect on health status among Palestinians.

There was semi-quantification of generated hypotheses in theory following surveying of a sample of university students in Hebron, confirming to a satisfying extent that the categories sorted under the main category of violence factors in occupation was relevant to the surveyed population, a conclusion hyperpolarized to be valid for the general population as well, considering exposure. However, only a limited effect on Health-Related Quality of Life or General Self Efficacy as measured by psychometric instruments was seen when comparing scores amongst groups living under exposure to a range of factors of occupation, such as living by the wall, crossing military checkpoints on way to work, being imprisoned or going through IDF or having relatives killed by settler violence.

Exploring emerging ideas from the perspective of this surveying confirmed that occupation is "all over the place" and suggested that effects of occupation are at the level of the collective, and not to the greatest extent dependent on individual exposure. Even if one could count a healthy worker effect on the questionnaire data, other data analyses suggest cultural context as an explanation of coping in the general population and a possible explanation for the lack of any significant difference among samples. 
Individual exposure to factors of occupation is a part of a collective experience, with coping techniques, strategies and tactics derived from this collective experience. The experience is described as resistance rooted in Palestinian culture, for Palestinians are known as sumud (stubbornness) and the political context is a re-representation of narratives in the field making sense of counter strategies and resistance tactics against factors of occupation. Where violence factors of occupation are the most visible obstacles to health and access to health care; structural factors can be more severe on a national level. The emergence of several strategies and tactics creates an order rooted in all societal levels, from individual coping to national level via the family, community and state.

Resistance, including concepts such as coping, strategies and tactics, constitutes the second core category. Resistance is composed of strategies and tactics in the agency of the Palestinian population, and in this study, it is focused on the health system and individual actors within it, such as those interviewed. Resistance is seen in all of Palestinian society, from the individual level to the national. From a foreigner's view, it could be understood through its cultural rootedness in sumud or as kin to the resistance depicted in art and ethno-cultural identity. This resistance also includes organizational sub-categories within NGOs, especially the PNGOs with their stronger local ties based in the communities. One key tactic to defeating barriers of occupation and lessening effects of isolation is using mobile clinics, as well as other directed initiatives. These coping techniques, strategies and tactics, especially when depicted as resistance, are examples of human activity creating meaning and coherence.

\section{Effects of isolation as an "all over the place" situation}

During research, the focus of the study shifted from "health in general" to "mental health", hypothesizing it would be a key theme given the presumed eminent effects of Occupation on the population in Palestine. No single diagnoses of somatic disease emanated directly from initial research data, except for those directly associated with physical violence, while 
existential issues and related questions were more common, such as those regarding individual and collective development, social coherence, quality of life and community progress in interviews.

The occupation is affecting everything in this country. Economy, safety, movement. If I want to do something with my children, go to the water park outside the city: entrance fee. Not only that, I pay for gas - if I have a car at all. And when I'm driving on the road I get to checkpoint. There, if a soldier is in the BAD mood he shoots me or my kids. Or if a settler comes, and he is in the GOOD mood - he shoots me or my kids. Of course, this gives very bad quality of life in Palestine - and, affects thinking. I'm always thinking, thinking, will something happen? M30

“The problem is not in the population, authorities or who's in government, it's the political situation.” (Interview, M50)

In the field, factors of Occupation that affect people's daily life are apparent in several ways, in geography, social arenas, and people's subjective and group-based experiences. The health situation and the standard of living, the quality of life and burden of disease all vary between diverse groups, depending on whether someone is a worker, city dweller, camp refugee, village inhabitant, person living near the wall and so on. The effects of occupation differ depending on who someone is, and socio-economic status and level of education are also of importance. These factors are related to obtaining employment and getting access to health information, and hence relate to utilization of health resources and health services.

All these factors have effects on health in Palestine, as in any other country. However, Palestine does differ from many countries in the way that it is occupied, and the occupation is also affecting these determinants. Early data suggested abandoning straighter biomedical 
definitions of health and disease. Soon after reading the literature, the concept of Quality of Life emerged to take the place of "health" of our initial approach.

\section{Occupation as apparent in everyday life and its determinants of health}

Occupation is a nuisance, making life in Palestine difficult and creating anger and despair among people. Palestine is dependent on foreign aid and non-coherent social economic politics, secondary to difficulties of building its state, as suggested by interviewees. Recurrent in data is the setback of the Palestinian economy that took place post-second Intifada, with rising unemployment preceded by a shift of Israeli policies regarding praxis and relations to its neighbors. Palestinian workers, who were dependent on work inside Israel to a considerable extent, became unemployed because they lost their working permits when Israel tightened its border restrictions. Together with factory closures in the West Bank, this policy change affected household incomes and the economic situation of families negatively, especially their female members. According to a female health care worker from Ramallah, "work is important to maintain enough to support to the family life, for the rising expenses, good housing et cetera indeed affecting quality of life, education and retreatment. So many things are rooted in the occupation. /.../ The norm is that males should not show feelings, instead he beat his wife or daughters". She continues: "The women issues are important, the checkpoints, intifada and wall have all resulted in an increased domestic violence" (Interview, F50). Although affecting all of the population, data suggests that occupation's effects are gender-biased.

Because there's low education, women don't have a good position in society. They are not in school to same extent as man, the marriage is early, 15-16 years of age, and no jobs for them. The family prevent them from going from home, to get to hospital they often need to have a brother with them, or when she want to go she must take 
permission from her husband and also beg for money [for the treatment], she depend [too much] on her husband. M40

Domestic violence, divorce, early marriage and separation are critical issues to be discussed with Palestinian women. Due to economic hardship, early marriage is an economic relief for the families of the couple. Occupation have effects ranging from changes to national policies to young females in Palestinian families living with constrained household economies, as the situation is "all over the place" affecting determinants of health.

\section{Isolation and its constituents}

Isolation affects all of Palestine on a national level, especially considering its hardships developing as a country with system stability. On the local level, isolation is as concrete as the wall surrounding Palestinian municipalities along the green line. This could be illustrated by the trapping of harvest land from Palestinian farmers or by its cutting of roads, splitting communes from coherent societal entities into disintegrated parts of a once-community now being destroyed by a wound. The wall constitutes one of the biggest barriers of occupation in Palestine in many aspects.

Physical barriers causing isolation cannot be subtracted from a context of occupation in Palestine. Barriers include but are not limited to the wall, military checkpoints, flying checkpoints installed on ad hoc basis, permanent settler roads, curfews, military raids and areas in control of IDF.

\section{A local hospital as an example}

Our hospital provide service to [multiple] villages of [the] district. The situation has went from worse to worse since the $2^{\text {nd }}$ intifada when the Wall was built, and when the [flying] checkpoint came. But we have to live this life and we struggle to change something. All people are affected by the wall- 
Qalqilya is surrounded - and we are living like in a bottle. (strangle gesture)

We live the worst kind of life, every moment - but we have to live, and anyway we don't know what a good life is. F40

In Qalqilya, the wall surrounds a central municipality, physically dividing its core where most of its inhabitants live, from the area that used to be the now trapped community's periphery and where the farmers have their lands. The wall also shuts off an underground river supplying water to dwellers. The wall is 2-8 meters high, made of concrete and steel, and equipped with razor wire and watchtowers reaching out to the sky, where patrolling armed soldiers look down on farmers standing below, no longer in natural contact with the soil on the other side, but waiting at a gate to be let in by a foreigner, or if the permission to come out is outdated, applying for permits to be let in through a lengthy procedure. The same picture illustrates the situation in numerous communities along the land the Wall has been placed upon. The wall in Qalqilya has a few entrances that are open for half an hour or so morning, evening and lunch, when farmers can pass through to their soil to harvest it, if given the right kind of permission by Israeli soldiers.

The Qalqilya hospital, which is near the village checkpoint but not in the village itself, has many of its staff amongst the village dwellers. It employs personnel from all work categories but cannot run on full service due to the restrictions created by the installment of the checkpoint. Because incidents often create delays in queues to the checkpoint and because of the frequent raiding by the Israeli Military in the area, fear of violence in combination with the uncertainty of coming home after work has made the hospital a less attractive workplace.

Another issue for the hospital is recurrent delays in salary payments to employees, along with its overall financial situation affected by a recent economic crisis in the EU, which has cut a considerable amount of its financial aid to the NGO running the hospital. The same task stands before the governmental health service providers; keeping its employees despite an 
inability to provide salaries on time and harsh working conditions is a difficult problem. This situation is a cause of brain drain, discussed in later chapters.

The hospital needed an ambulance at the time of research but lacked the financial capacity to invest in one. Patients discussing with us had problems reaching the hospital because gasoline prices were high, they did not have a car, or they could not afford the taxi or the local shuttle bus. Transportation of patients is difficult not only due to the expense of gasoline and vehicle access but also because of bad roads.

Trapping areas between barriers endangers access to health care for affected dwellers. It makes access more difficult, with a situation that demands increased planning for those in need of seeking health care, out of fear of violence from Israelis, soldiers in military checkpoints or settlers in settlement areas. This is also an issue in Halhoul, on the outskirts of Hebron:

The location of the center is in Old City - surrounded by settlers and checkpoints. Many times they close [the checkpoints] and don't let anyone move [which] makes problem to people when they try to come here. Sometimes settlers or military attacks with gas bombs, the soldiers close the streets [in order to] keep us here for many hours. They have a closing policy making people afraid to come here to get their treatment. M40

Transportation difficulties isolate families living in occupation and violates the human right to free movement of people. Movement restrictions are an acute effect of barriers and affects access to health care negatively, according to interviewees.

Since a functional state structure is lacking, large parts of the social security in society is informal, including the welfare system, as there is no governmental social welfare. This informal structure has weakened as transportation difficulties have risen and traditional social 
networking has become more difficult. A woman describes this loss of social networking possibilities as "we [Palestinians] lose a part of our life in terms of loss of social capital for the social resources." (Interview, F50) Social networking has deteriorated due to obstacles in movement. Marriage between people from the West Bank and Gaza is no longer possible to the same extent because of difficulties in movement affecting the possibilities to meet. Transportation and movement, and the obstacles circumfusing it, preoccupy young Palestinians in many aspects of life. During a field study in 2008, a young medical student referred to this situation, claiming that the first thing a proponents asks his potential partner is "where do you live?" to determine whether he or she has the right ID and ability to reach possible common areas (Andersson, Pehrsson, \& Fridlund, 2008). Current study interview data indicates that because of factors associated with the Occupation, and especially because of the barriers, poverty is increasing. Movement restrictions are also weakening social coherence, thereby affecting a key determinant of health in the Palestinian society and population.

\section{A variety of barriers under occupation}

There is a variety of barriers under occupation in Palestine that affect different groups, including the difficulties in checkpoints. Palestinian children are affected by checkpoints when going to school. This creates a loss of comfort in the lives of Palestinian parents, inducing distress that causes sadness, anxiousness, shouting and crying. "I don't feel good until I get to know that my son has returned safely home to our house from hi school after finishing. We are feeling insecure, we are threatened, have a feeling of the unknown." (Interview, F50)

Since the building of the wall along the country, the wall has had an effect of causing a general and long-lasting fragmentation, not only of the land itself, due to roads, wires and walls, but also of Palestinian control contributing to its loss of power, which is replaced by the 
IDF and potential violence. This violence recurs in data, and during field studies we witnessed crimes in direct violation of international law. These included soldiers raiding a hospital, breaking in uninvited and standing on its grounds aiming with rifles on school age kids and shooting at young men demonstrating against the building of the wall that would divide the village from its farm lands. The lack of consequences for law enforcement by IDF and the unpredictability of settler's violence creates a sense of loss of control for those affected.

\section{Questionnaire survey}

Factors of Occupation that sustain isolation, according to the emerging theory, include the wall to Israel, military checkpoints, potentially deadly violence and IDF policies of detention and imprisonment. For semi-quantification of the relevance of these emerging categories to health and access to health care, the following survey was conducted. 105 questionnaires were administered, of which 99 were collected. One was blank, leaving 98 forms in total for analysis. Items containing 90\%> completed answers were included in further analysis, which included all 98 of the SF-36 forms, 90 of the GSE scale forms and 90 of the sociodemographics forms. Socio-demographic data outcome $(n=90)$ suggests that the students who participated had a mean age of 21 in the age range 18-24, with an average of 1-5 years in academia. 
Table 1: Number and relative proportion of gender in participants $(n=90)$

\begin{tabular}{llll}
\hline Gender & Female & Male & n/a \\
\hline $\mathrm{N}$ & 48 & 37 & 5 \\
$\%$ & 53 & 41 & 6 \\
\hline
\end{tabular}

Table 2: Household income in NIS

\begin{tabular}{llllllllll}
\hline Income & $<1000$ & $1000-$ & $1500-$ & $2000-$ & $2500-$ & $3000-$ & $3500-$ & $4000>$ & \\
(NIS) & & 1500 & 2000 & 2500 & 3000 & 3500 & 4000 & & \\
\hline $\mathrm{N}$ & 8 & 12 & 8 & 11 & 6 & 26 & 6 & 13 & 90 \\
$\%$ & 9 & 13 & 9 & 12 & 7 & 29 & 7 & 14 & 100 \\
\hline
\end{tabular}

Table 3: Number and proportion of students passing military checkpoints $(\mathrm{CP})$ and the number of checkpoints on way to work

\begin{tabular}{llllllll}
\hline Passing & Exposure & $1 \mathrm{CP}$ & $2 \mathrm{CP}$ & $3 \mathrm{CP}$ & $4 \mathrm{CP}$ & $5>\mathrm{CP}$ & $\mathrm{n} / \mathrm{a}$ \\
\hline Yes & $34(38 \%)$ & 4 & 16 & 7 & 3 & 3 & 1 \\
No & $52(58 \%)$ & & & & & & \\
$\mathrm{n} / \mathrm{a}$ & $4(4 \%)$ & & & & & & \\
\hline
\end{tabular}


Table 4: Number and proportion of students exposed to violence factors of occupation (spec.)

\begin{tabular}{lllll}
\hline Type of exposure & Exposed & Unexposed & n/a & $\%$ exposure \\
\hline Living by the wall & 8 & 79 & 3 & 9 \\
Martyred family & 15 & 72 & 3 & 17 \\
member & & 63 & 3 & $28 \%$ \\
Family member in & 24 & & & \\
Israeli army prison & & & & \\
\hline
\end{tabular}

WALL

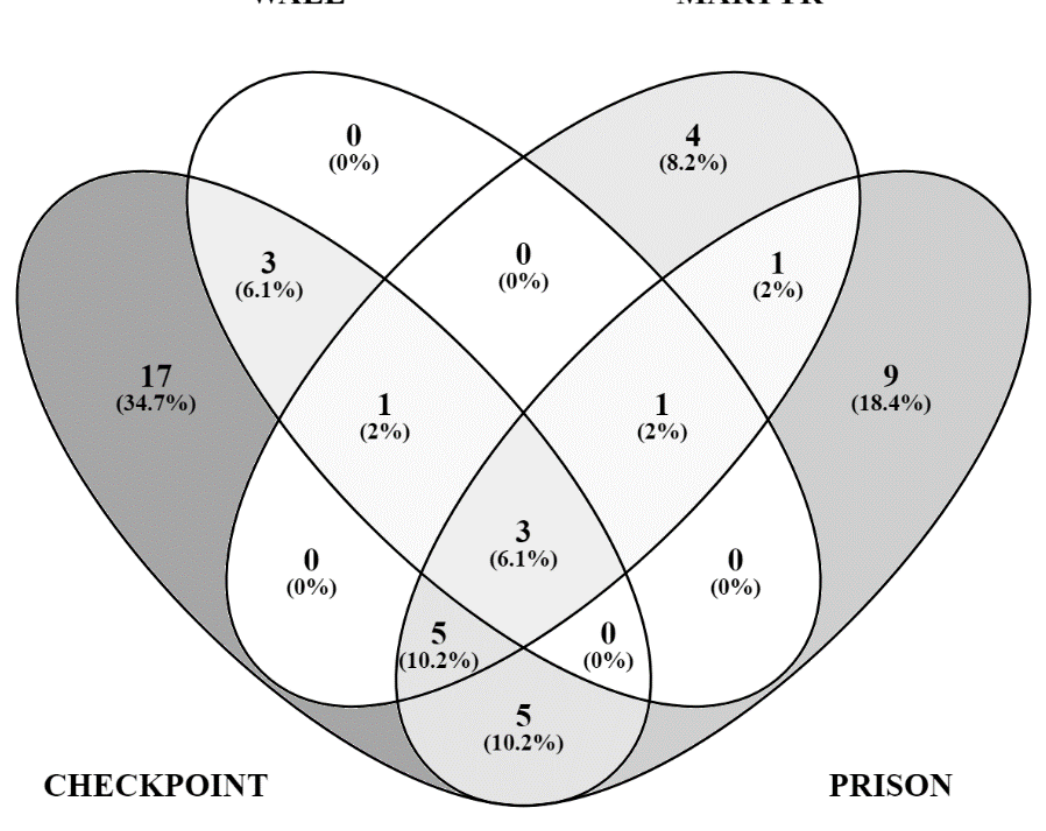

Fig. 1 
Fig. 2

QUALITY OF LIFE

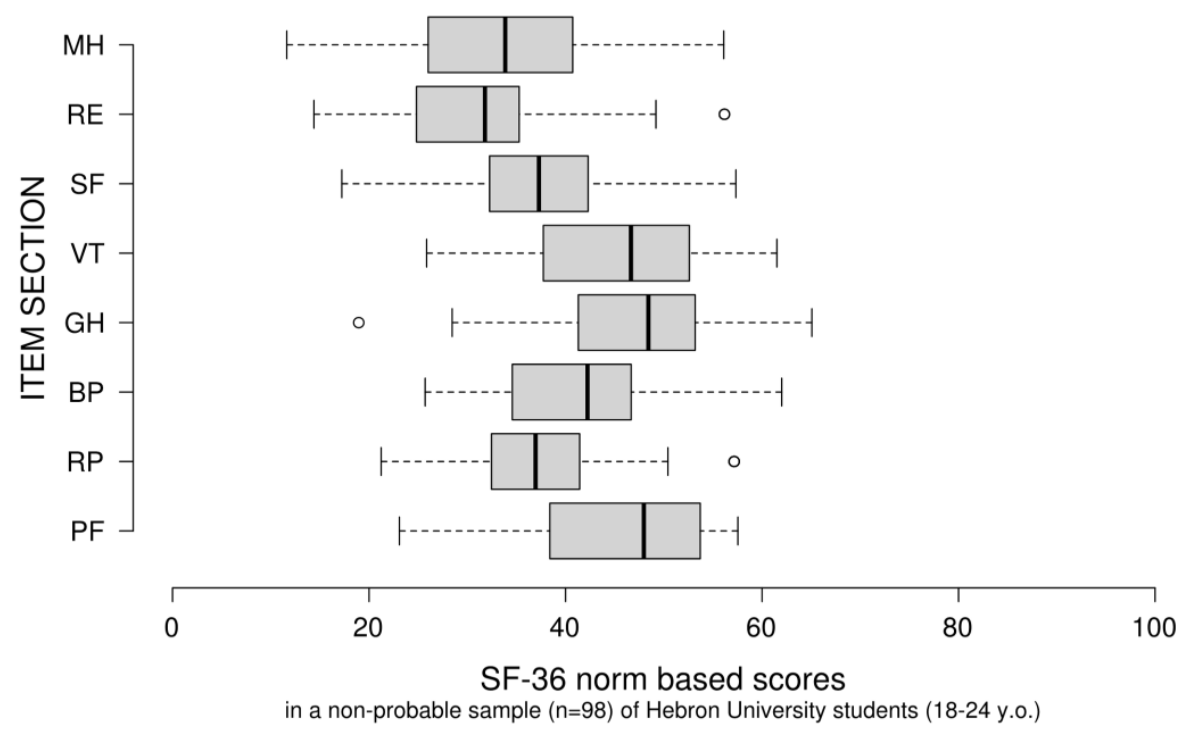

Figure 2: SF-36 results show the following baseline score values for the total sample, with the mental item score categories considerably lower than physical scores. Abbreviations in the item section stand for Mental Health, Role Emotional, Social Functioning, Vitality, General Pain, Bodily Pain, Role Physical, Physical Functioning.

Center lines show the medians; box limits indicate the 25 th and 75 th percentiles as determined by R software; whiskers extend 1.5 times the interquartile range from the 25th and 75th percentiles. (R, 2018) 


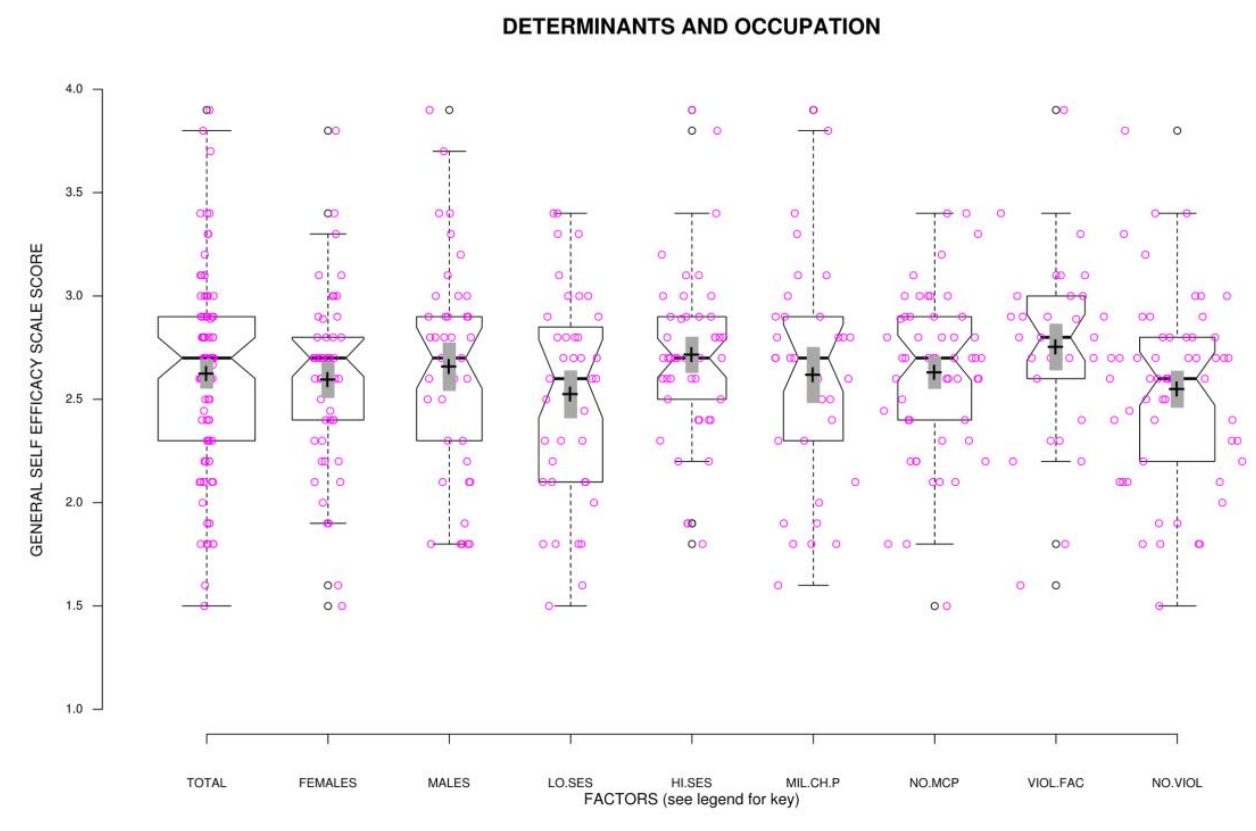

Fig. 3

Figure 3: GSE baseline score for total sample, determinants and factors of Occupation ( $n=90)$. Abbreviations: Total, Females, Male, Low Socio-Economic Status (household income < median), High Socio-Economic Status (household income $\geq$ median), Military checkpoints on way to work and negative control, Violence factors of Occupation (living by wall and/or martyred family member and/or family member in prison) and negative control.

Center lines show the medians; box limits indicate the 25 th and 75 th percentiles as determined by R software; whiskers extend 1.5 times the interquartile range from the 25th and 75th percentiles, outliers are represented by dots; crosses represent sample means; bars indicate $90 \%$ confidence intervals of the means; width of the boxes is proportional to the square root of the sample size; data points are plotted as open circles.

Scoring on the General Self Efficacy Scale showed significant differences in confidence interval in comparison of means of two categories compared to the negative control, but not compared to the total sample. Categories are factors of occupation, including positive answers 
regarding martyred relatives, relatives in prison and/or living by the wall and socio-economic status: high income is related to higher GSE mean, and violence factors of occupation are related to higher GSE mean than not to have such experiences. The latter is true for the median deleting outliers.

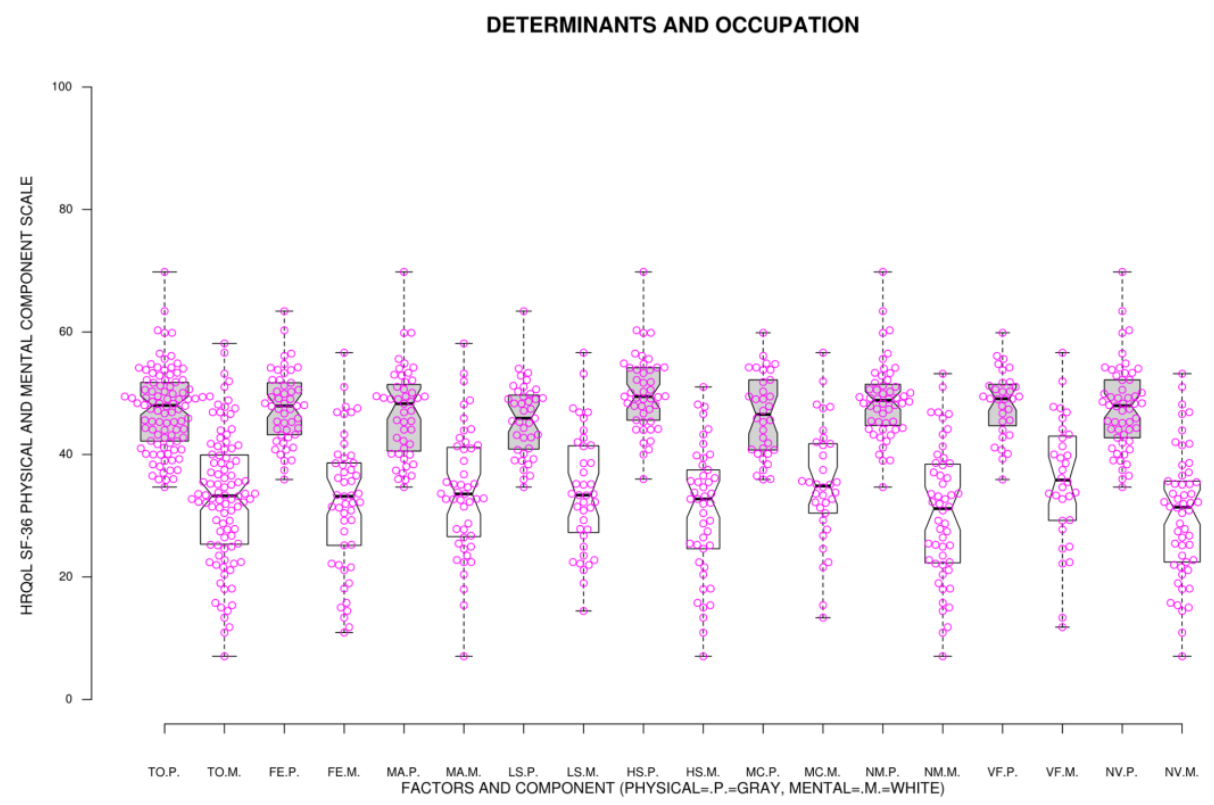

Fig. 4

Figure 4: SF-36 baseline score for total sample, samples based on determinants and factors of Occupation ( $\mathrm{n}=98)$. Abbr: Physical (gray boxplots) and Mental (white boxplots) component scores for samples of Total, Females, Males, Low Socio-Economic Status, High SocioEconomic Status, Military CheckPoints on way to work and negative control, Violent Factors of Occupation and negative control.

Center lines show the medians; box limits indicate the 25 th and 75 th percentiles as determined by R software; whiskers extend to 5th and 95th percentiles, outliers are represented by dots. The notches are defined as $+/-1.58 * \mathrm{IQR} / \mathrm{sqrt}(\mathrm{n})$ and represent the $95 \%$ confidence interval for each median. Non-overlapping notches give roughly $95 \%$ confidence that two medians differ, i.e., in 19 out of 20 cases the population medians 
(estimated based on the samples) are in fact different (Chambers et al., 1983). Width of the boxes is proportional to the square root of the sample size; data points are plotted as open circles. (R, 2018)

The determinants and occupation factors showed no significant differences in HRQoL scoring according to SF-36, but the trend for violence factors is comparable to the difference in the corresponding GSE sample.

\section{Strategies and tactics in coping and resistance}

Here's a really bad quality of life. On a 10 point scale I'd say that it's a 1 pointer, or maybe 2 - really, I can't understand how they manage to live here. Everyday there's a chance they may lose their life. We try to come here to give them medical support free, free checkup exams and free medication. The economy is very bad, they are counting on their plants, they sell them. Those who have a car go outside to sell the plants - the others get to the main road and take a taxi. By time they've got used to it. And others, who don't get used to it, leave. Those who stay know how to deal with Jews and live with it. Here's tougher than other places in Hebron. (Interview, M28)

Using the questionnaire outcomes for analysis with far-fetched conclusions is not possible, since it is designed for exploratory and descriptive purposes only.

Emerging concepts in the qualitative section, however, suggested that factors of occupation were of importance to a considerable share of the Palestinians, changing the scope from a narrower pathogenic frame to a more human, common sense, and everyday-life view that should pique the interest of any Palestinian or Palestinians as a group, rather than of only the sick who ought to be cured by intervention. If not assuming a significant healthy worker effect, the questionnaire results are in line with such effects. Coping with factors of occupation can occur at a group level, hinted at by data and further explored in the research that followed. 
Palestine has developed strategies for the health system, as an order of externally imposed contingencies on its dwellers has not changed for a long time.

As in the case with Halhoul their health center was built to avoid the effects of checkpoints to Hebron, lessen burden of disease and death casualties when patients wait for health care. While this is a direct example of occupation's effects on access to health care and tactics battling it, the possibilities to provide services of the same health center is affected in more indirect ways as well. "We have deficiency of equipment in the center, scissors, examination gloves - name anything. Checkpoint give a financial situation deficiency, but it even affects everything in our life. An example, if there's a medical meeting in Ramallah and there's control on the checkpoint, if the mind of the soldier is not good, he let you wait for 3-4 hours, or he say you cannot go at all. The same if you're studying." (Interview, M36)

Other societal strata strategies can be seen in lower structure levels, such as community groups, the family or the individual. On the individual level, every person has his or her own set of strategies, adjusting for the situation he or she is under. It helps in everyday life to not stand without solutions to emerging problems in a reality of limited control. In data, several subcategories under the resistance and strategies/tactics categories emerged and were not limited to actors in the health sector. Regarding issues of health and health care strategies, tactics are used as means to different ends.

People don't have access to healthcare. There are roadblocks, and checkpoints, making people don't go to the city for treatment. Also, this is C-area, and no Palestinian police are here. The wall stops entrance for people to Israel, to work, to get health care. M36

According to the interviewees, the biggest problem working within the sector of mobile clinics for access to health care are the flying checkpoints installed by IDF in the community, hindering people to access the main road and reach health care facilities with ease. For the local hospital, another barrier to health care is expensive out-of-pocket patient transportation costs. To reach out to community 
inhabitants, these obstacles are shunted using mobile clinics, where an ambulance with basic equipment and medications regularly comes to facilities in local communities that are rural or in other ways isolated due to barriers, for its dwellers receive a checkup or get treatment or referral depending on the issue and cause of health care seeking.

Coping could also be illustrated by the health care staff's individual solutions for issues resulting from factors of occupation. "We [staff] have to leave the hospital early, sometime between 3-4 o'clock - 8 pm they [IDF] close the area," M66 tells us, describing how daily recurrent military closures of the hospital area affect not only patients' access to health care but health care staff's access to their work place and the hospital's access to its work force, who in this case bases its shift hours on IDF's patrolling schedule. The employees leave work before a nearby checkpoint closes the area for movement of people for the day. Another individual tactic is fluidity regarding choice of place to work.

Salary is very low, even if I work 12 hours I may get paid for 3. If I don't have salary in end of month - sometimes for many months - what work will I do? I will go somewhere else, not coming to a place that doesn't pay me. M30

HWC, UHCC and PMRS are health-oriented NGOs that developed from organs programmatically representing their political factions later evolving into independent organizations, a process which partly was made possible through international aid from European and Gulf countries. The creation of NGOs in Palestine that take responsibility for the health of the Palestinian people did occur when the needs for health services were neglected for over a decade under Israeli military rule after 1967, which ended the eras of the Jordanian and Egyptian Ministries of Health in West Bank and Gaza. Since the PA entered the Health System and since the creation of the Palestinian Ministry of Health, the health committees have defined its mission together with other grassroots organizations in Palestine under the Palestinian Non-Governmental organization network working for stability and progress in a Palestinian state recognized by the international community. These health NGOs 
have kept their role on the ground, trying to bypass the wide range of barriers that have been raised, creating intermittent and chronic states of isolation in large areas restricting both the physical and internal realities of its dwellers. Breaking the isolation and removing the restrictions is a goal in the health committees' counter strategies against the Occupation power.

As you can see I don't have impressive muscles, I'm short and fat. It was a pity as a child, because I wanted to be like the hero, strong and with a trained shape of body. God played me a trick because he put the muscles in my brain. That's why I became a physician and not a soldier, which is my way to help my country. I can't be the armed fighter in field, but I'm here at the hospital to take care those who are. M40

People rely on organizations to provide food and services, but they can find their own coping strategies in everyday life. Weaker groups in society suffer more in general, and pinching has become an art for lower socio-economic strata. The Palestinian government has target groups for various initiatives, such as for the women or the disabled. The lack of a functioning state still leaves a demand for a coherent policy, in place of the present government support policy of covering selected groups spot-wise and intermittently. While waiting for this to happen groups organize in their communities, creating community-based programs with local solutions to problems which otherwise would stay unsolved.

The health work committees give health care and education, for example lectures about the breast feeding. Last year we had the "Well Baby Project" were all 5 year olds were checked up, length, nutritional status et cetera and we had education for mothers with brochures. The economic crisis in Europe came and unfortunately we had to stop - no donors, no service. As our services are free or at a low cost, if we have no donors we can't give anything. F43 
Another example is described in the zakat committee, a community-based network that is an Islamist type of welfare bureau with religiously colored motifs. It is active on the local level and usually not organized in a regional or national affiliation, where it often is constituted by academicians and business men. Sorting under the inventory of religious organizations registered in the PA ministries of Religious affairs, the network is officially under control of the Palestinian state. Based in Islamist thought and with a member base with an inclination toward piousness and godly acts, they are viewed skeptically by other actors in the Palestinian NGO sector.

The educated professionals in Palestine have a challenging time motivating their choice of country in a global world. Young people often graduate, but it is difficult to find a job corresponding to the level of education. Palestinians do not have permission to work in Israel by default anymore, as this was where most Palestinian working-class members' jobs used to be. Instead, they look to the possibility of obtaining aid of some kind, and this is related to efforts in education for young people. This situation has created a large base of an extremely well-educated underclass. Many Palestinians have degrees in academia but no job opportunities. This results in brain drain, making educated professionals leave the country. This movement affects not least the medical community, where an improvement in working conditions for general practitioners would make it more attractive to work in the country for a large share of physicians, according to key informants.

\section{Discussion}

Results from this mixed methods study with a grounded theory approach suggest that isolation as a theoretical concept is of use to describe a main concern for Palestinians, especially regarding health and its determinants as well as access to health care, resulting 
from barriers in policies of occupation. Another concept emerging from the analysis was tactics and strategies against occupation in society.

Data suggests that since a functional state structure is lacking large components of the social security system, much of the system is informal, including the welfare system, as there is no governmental social welfare. This informal structure has been weakened as transportation difficulties have risen and traditional social networking has become more difficult, an argument presented by Hilal (2006). We argue that young people often graduate, but it is difficult to find a job corresponding to the level of education, as discussed by Sayre (2009). This creates brain drain, making educated professionals leave the country, which our analysis suggests affects the medical community. An improvement in the field of family medicine would make it more attractive to work in the country for a large share of physicians, as argued by Andersson et al. (2008) and reflected in the work conditions of Palestinian health workers.

Palestinian children are affected by checkpoints when going to school, as reported by DCI/Palestine (2018) on the issue of Israeli systematic detention of children. This creates a loss of comfort in the lives of Palestinian parents, leading to distress and emotional responses, such as described by the woman who could not relax until she knew her son had returned safely home after school. While this is an example of how barriers (in this case military checkpoints) affect Palestinians by creating fear, it is also an example of the cohesion of family that is recurrent in Palestinian lives. This is a factor to include in the category of tactics described in findings, relating to the conclusions of Kimhi, Eshel, Zysberg, and Hantman (2010), who found family cohesiveness and sense of danger as important factors correlating to distress of conflict and recovery in Israeli youths during the Lebanon War of 2006.

The Palestinian government has targeted groups, such as women or the disabled, for various initiatives, nominally trying to find ways to support these groups. The lack of a functioning state still leaves a demand for a coherent policy, rather than the present government support 
policy of covering selected groups intermittently, which also is argued by Bosmans, Nasser, Khammash, Claeys, \& Temmerman (2008). Our study suggests that this need is partly covered up by regional NGOs like HWC, UHCC and PMRS. This situation is questioned by Schäublin (2009), who argues that zakat committees could be more rooted in local society according to the limited research available on the societies where they are active, and that while secular NGOs supported by US and Europe are accused of being experts in applying for grants but not using the cash on the ground, the zakat committees consist of respected men working voluntarily to keep life in their local communities and its individuals.

We found that the focus on mental health as described in psychopathological terms is criticized within the field of public health in Palestine. For example, using PTSD in the context of Occupation would not consider the collective experience of an unjust political situation; it would simply invent categories for individual intervention that are not necessarily relevant to helping those affected or offer any solutions in the long run, as according to Palestinian discourses on the subject (Rita Giacaman, Shannon, Saab, Arya, \& Boyce, 2007). In addition to making the situation an individual problem rather than a collective problem, the use of mental disease categories in the field is also impractical because of stigma. Rather than focusing on health in general, we narrowed the scope to mental health, which the literature suggested was important. Based partly on these considerations, Quality of Life appeared as a more valid category of common sense when discussing effects on the Palestinians' in its full range as a population.

In the scientific field one possible theme to explore further is the question of how those who live through traumatic events keep carrying on, as in the case of students whose Quality of Life scores in SF-36 seemed higher if they had experienced violence. Here, further qualitative research is needed to be done to generate stable hypotheses for more powerful testing. 
Hopefully, the suggested blueprints of emerging theories in the findings could be meaningful for developing and exploring this topic further in future research.

Regarding the questionnaire, in the data it was not possible to find any remarkable conditions that stood out using SF-36 or GSE. The assumed small but positive correlation with violence factors of occupation in the statistics could be a "healthy worker effect", but it is still noticeable that what are perceived as traumatic incidents do not show effects on wellbeing relative to the controls. If the effect is congruent with other findings, it may tell us that the effect of violence is dependent on the tools to handle it. It could also be the case that occupation influences the students collectively where individual specific exposure is of lesser importance, or that their defense mechanisms are collective. A later study from Hebron comparing $\mathrm{H} 1$ and $\mathrm{H} 2$ respectively (areas which differ considerably regarding exposure to settler violence and checkpoints) by Fasfous, Peralta-Ramírez, and Perez-Garcia (2013) finds that there is no difference in incidence of PTSD among the groups, although the type of violence from soldiers and settlers differs in severity. It would be of value to see if this finding could be related to the same cultural context the groups live in.

When talking to professionals and patients, it was difficult to see any diseases directly related to occupation. Discussion and theoretical sampling of the field data from community-based health care programs showed a high demand for treatment for mental diseases. However, when meeting people with experiences of violence, imprisonment or torture, they seldom talked about their experience as traumatic per se without context of occupation. While research confirms PTSD-associated symptoms to be overrepresented in populations of Hebron in zones of chronic conflict, its meaningfulness as a category is not emerging in the field. Giacaman (2011) makes a point addressing the need to evaluate current health measures and develop new ways to create numerical data linking health to a widened context in which people live their everyday lives, a point which we embrace. 


\section{Limitations}

This study was carried out within several PNGOs active in the medical field. These organizations stem from Palestinian political factions (Popular Front for the Liberation of Palestine, Democratic Front for the Liberation of Palestine, Palestine Communist Party); considering that the data was extracted from interviews and observations within these organizations, it is adequate to suppose that the results tend towards themes highlighted by the agendas of these social movements. The aim of the researchers, however, has been to have a maximum variability in data sources during open sampling to understand the situation, so key informants from other organizations and authorities have been consulted, including officials within the PA, Islamist, Christian etc., albeit to a lesser extent for the project than the milieus of secular nationalist, progressive values as presented in these NGOs. In this study, the situation in Gaza is not mentioned. The reason is that Israeli authorities denies entrance to Gaza under its military blockade. Since the aim of the study has been to collect data in the field, Gaza has been left out and must be addressed by future research. The Gaza question is indeed an important one, dealt with accordingly by Olofsson and Österholm (2016) and in the context of global health and from a medical perspective by Gilbert and Fosse (2009).

For data corroboration and triangulation, the results have been coded with relation to existing research and scientific topics in the theoretical sampling in accordance with a GT approach to add richness to emerging concepts. Studies of Fasfous (2013) and Nashef (1991) are worth mentioning again, as is Giacaman's discussion on valid categories to explain effects of occupation.

The results of this study are vague in nature, mostly due to the author's uncertainty with the GT method. While it indeed was interesting to study the methodology of this empirical framework with an inbuilt purpose of exploration, the method was intuitively hard to grasp initially. When sampling had begun, and coding was in progress, it was difficult to narrow the 
focus. The method was data-heavy and it was difficult to find an overview. The research objectives were too broad, and it was after stating the objectives that we understood the concept of "following the data" in grounded theory. This is a practical problem, since project plans often require objectives in form of proclaimed questions.

However, this method has made the thesis range wider in content, which is interesting as an orientation to the topic. While it is the purpose GT to be conceptual and not descriptive, it is questionable whether GT was the "right" method or if other QDA would have been more appropriate. On the other hand, the findings are richer than if a plain content analysis of data had been used, with constant comparison and sampling with purpose to empirically "ground" data analysis. The goal in data collection in grounded theory is to reach "data satiety". We never reached this stage, so the "theoretical coding" should lead to more advanced theory regarding the phenomena in the core categories in a generalizable manner, but this never occurred. If it is possible to label it conceptual theory at all, and the reader does not conclude that the study is a kind of descriptive analysis, the highest theory reached in current work is what Glaser (2004) called substantive theory, which is valid in its own setting but without drawing any advanced theoretical conclusions that are transferred to other situations.

\section{Conclusion}

The aim of study was to find out whether occupation in Palestine affects health and access to health care through interviewing key informants and conceptualizing around emerging themes in interviews and memo field data. We conclude that Palestinians are affected by the same biomedical diseases as the rest of third world countries undergoing a shift in disease panorama from infectious to non-communicable diseases reflecting modernization and life style. Rather than focusing on health in general or specific diagnoses, emerging concepts in data analysis suggests that quality of life is a valid topic to study qualitatively and psychometrically. 
In this field, factors of occupation with an assumed effect on quality of life in the geography and social arenas as well as in people's individual experiences are described. While the suggestion of a relationship between factors of occupation and quality of life was not supported by our survey, based on a questionnaire including SF36 and General Self Efficacy scales exploring associations between health and individual exposure of occupation, it was suggested by concepts emerging from studying the field with a GT approach. Further, it could be argued that the occupation is an "all over the place" situation, in which Palestinians collective in the same political and cultural context are working to solve the effects of occupation rather than being in need of individual interventions, other than those most affected (as in Gaza or Area C).

The isolation of Palestine and Palestinians under occupation and isolation's implications for the social life is a recurring theme in data, most often relating to material conditions in the physical life but also in the shaping of identities. The isolation is a result of a set of barriers, physical and abstract, including borders, the wall and checkpoints. The physical barriers obstruct possibilities for networking and for social interaction by imposing movement restrictions on the dwellers in the country. Effects are severe, since members of the Palestinian society largely depend on the economic security provided by family. The barriers constitute difficulties of transportation in everyday life, affecting the access to health care negatively but also affecting other determinants of health. For the worker, the transportation barriers mean loss of income and professional development; for the student, they mean obstacles in opportunities for professional development; for the patient, they mean access to health care often is denied by the occupant. Barriers include physical infrastructure such as the wall, settler roads, checkpoints and area divisions of the country that limit access for the native population. Barriers also include abstract categories such as fear of losing dwelling rights in case of absence and fear of violence from settlers and soldiers. The wall surrounding 
the West Bank is a large problem for those who live between it and the green line due to its division of the national geography into entities whose dwellers are separated from each other. All of these circumstances creates stress with a possible negative effect on health and quality of life.

In this "all over the place" situation, strategies and tactics are used to overcome the hardships of isolation under occupation in everyday life. These include several categories from the individual to the societal level. Creating a set of ad hoc strategies, Palestinians deal with obstacles experienced by barriers, isolation and occupation using coping techniques. Within the study the work of PNGOs are described as one such strategy, creating agency for Palestinian people in their needs while waiting for a functioning state without the limitations of occupation.

\section{Acknowledgements}

The researcher would like to dedicate this work to his children, Ethel Mary Siggesdotter and Cassius Rune Schafferer, and with thanks to their mother without whom this thesis project would not have been possible. Credits to Myra Åhbäck Öhrman and Johannes Nilsson for proofreading and to Tobias Thörnblom for the cover image. Thanks to Emm for standing by my side through the project.

This project was carried out with generous economic support from Stena Line, Olof Palme's Memorial Foundation, Linneaus Palme Foundation and The Senior Crew of Gothenburg's Physicians' Association. This project was facilitated by GGT, HWC, UHCC, IFMSA-P, students of Hebron University, students of Al Quds University, Professors of Public Health Department at Bir Zeit University and the PhD students of Physiological institute, Pharmacological unit at Sahlgrenska Academy. This project would not have been possible 
without the counseling from Dr Hani Abdeen, Ms Shatah Odeh, Prof Motasam Hamdan and Prof Rita Giacaman. Lastly, a thank to my supervisor, Dr Gunnar Olofsson. 


\section{References}

Andersson, S., Pehrsson, M., \& Fridlund, M. (2008). Palestinas framtida läkare - ett internationellt utbyte i en tid av konflikt. Retrieved from Stockholm

Ankori, G. (2006). Palestinian art. London: Reaktion.

Baker, A. M. (1991). Psychological Response of Palestinian Children to Environmental Stress Associated With Military Occupation. Journal of Refugee Studies, 4(3), 237-247. doi:10.1093/jrs/4.3.237

Barber, B. K., McNeely, C., Olsen, J. A., Spellings, C., \& Belli, R. F. (2013). Effect of chronic exposure to humiliation on wellbeing in the occupied Palestinian territory: an eventhistory analysis. The Lancet, 382, S7. doi:10.1016/S0140-6736(13)62579-9

Beinin, J., \& Stein, R. L. (2006). The struggle for sovereignty : Palestine and Israel, 19932005. Stanford, Calif.: Stanford University Press.

Blumer, H. (1969). Symbolic interactionism : perspective and method. Englewood Cliffs, N.J: Prentice-Hall.

Bosmans, M., Nasser, D., Khammash, U., Claeys, P., \& Temmerman, M. (2008). Palestinian Women's Sexual and Reproductive Health Rights in a Longstanding Humanitarian Crisis. Reproductive Health Matters, 16(31), 103-111. doi:10.1016/S0968-8080(08)31343-3

Challand, B. (2009). Palestinian Civil Society: Routledge.

Clarke, A., Friese, C., \& Washburn, R. (2015). Situational analysis in practice : mapping research with grounded theory. Walnut Creek, Calif.: Left Coast Press.

DCI/Palestine. (2018). Defence of Children International/Palestine Web Page. 
Ewen, M., Sakit, M. A., Saadeh, R., Vialle-Valentin, C., \& Seita, A. (2012). UN Relief and Works Agency for Palestine Refugees in the Near East's medicine procurement processes and prices: a comparative performance assessment. The Lancet, 380, S15. doi:10.1016/S01406736(13)60197-X

Fasfous, A., Peralta-Ramírez, M., \& Perez-Garcia, M. (2013). Symptoms of PTSD among Children Living in War Zones in Same Cultural Context and Different Situations.

Fosse, G. (2009). Øyne i Gaza: Gyldendal.

Giacaman, R. (2003). Health sector reform in the Occupied Palestinian Territories (OPT): targeting the forest or the trees? Health Policy and Planning, 18(1), 59-67. doi:10.1093/heapol/18.1.59

Giacaman, R., Khatib, R., Shabaneh, L., Ramlawi, A., Sabri, B., Sabatinelli, G., . . Laurance, T. (2009). Health status and health services in the occupied Palestinian territory. The Lancet, 373(9666), 837-849. doi:10.1016/S0140-6736(09)60107-0

Giacaman, R., Shannon, H. S., Saab, H., Arya, N., \& Boyce, W. (2007). Individual and collective exposure to political violence: Palestinian adolescents coping with conflict. European Journal of Public Health, 17(4), 361-368. doi:10.1093/eurpub/ck1260

Glaser, B. G. (2004). with the assistance of Judith Holton (2004). Remodeling Grounded Theory [80 paragraphs]. Forum Qualitative Sozialforschung / Forum: Qualitative Social Research, 5(2), Art. 4,.

Glaser, B. G., \& Strauss, A. L. (2006). The discovery of grounded theory : strategies for qualitative research. New Brunswick, N.J.: Aldine Transaction (a division of Transaction Publishers). 
Gluck, S. B. (1997). The Feminist Nationalist Connection in the Palestinian Movement. In L. A. West (Ed.), Feminist nationalism. New York, N.Y.: Routledge.

Haavisto, P. (2010). Desk Study on the Environment in the Occupied Palestinian Territories. Retrieved from https://postconflict.unep.ch/publications/INF-31-WebOPT.pdf

Hammami, R. (2000). Palestinian NGOs Since Oslo: From NGO Politics to Social Movements? Middle East Report(214), 16-48. doi:10.2307/1520188

Hilal, J. (2006). Class Formation, Conservatism and Palestinian Emigration. In L. z. Tarākī (Ed.), Living Palestine : family survival, resistance, and mobility under occupation - Gender, culture, and politics in the Middle East. Syracuse, N.Y.: Syracuse University Press.

International/Palestine, D. o. C. (2011). DCI-P Detention Bulletin. Retrieved from Jerusalem, Palestine:

Kimhi, S., Eshel, Y., Zysberg, L., \& Hantman, S. (2010). Sense of Danger and Family Support as Mediators of Adolescents' Distress and Recovery in the Aftermath of War. Journal of Loss and Trauma, 15(4), 351-369. doi:10.1080/15325024.2010.49176

Lindesmith, A. R., Strauss, A. L., \& Denzin, N. K. (1999). Social psychology. Thousand Oaks, Calif. ;: Sage.

Massad, S. G., Nieto, F. J., Palta, M., Smith, M., Clark, R., \& Thabet, A.-A. (2012).

Nutritional status of Palestinian preschoolers in the Gaza Strip: a cross-sectional study. $B M C$ Public Health, 12, 27-27. doi:10.1186/1471-2458-12-27

Mataria, A., Khatib, R., Donaldson, C., Bossert, T., Hunter, D. J., Alsayed, F., \& Moatti, J.-P. (2009). The health-care system: an assessment and reform agenda. The Lancet, 373(9670), 1207-1217. doi:10.1016/S0140-6736(09)60111-2 
Nashef, Y. (1992). The psychological impact of the Intifada on Palestinian children living in refugee camps in the West Bank, as reflected in their dreams, drawings, and behavior. Frankfurt am Main ;: Lang.

Neria, Y., Besser, A., Kiper, D., \& Westphal, M. (2010). A longitudinal study of posttraumatic stress disorder, depression, and generalized anxiety disorder in Israeli civilians exposed to war trauma. Journal of Traumatic Stress, 23(3), 322-330. doi:10.1002/jts.20522

Olofsson, G., \& Österholm, P. (2016). Vad händer i Palestina? [Stockholm]: [Gunnar Olofsson och Peo Österholm].

PCBS. (2004). Palestine - Demographic and Health Survey 2004. Ramallah, Palestine.

PCBS. (2012). Socio-Economic and Food Security Survey West Bank and Gaza strip,

Palestine 2012

Ramallah, Palestine.

PCBS. (2013). Palestine in Figures 2012. Ramallah, Palestine.

Rorty, R. (1998). Philosophical papers. Vol. 3, Truth and progress. Cambridge: Cambridge University Press.

Rorty, R. (1999). Philosophy and social hope. London: Penguin.

Sayre, E. A. a.-B., Samia. (2009). In Search of a Future: The Struggle of Young Palestinians. In N. Dhillon \& T. Yousef (Eds.), Generation in waiting : the unfulfilled promise of young people in the Middle East

Washington, D.C.: Brookings Institution Press.

Schäublin, E. (2009). Role and Governance of Islamic Charitable Institutions: The West Bank ZakatCommittees (1977-2009) 
in the Local Context. CCDP Working Paper(5).

Selby, J. (2002). Dressing up domination as 'cooperation': the case of Israeli-Palestinian water relations. Review of International Studies, 29(1), 121-138.

doi:10.1017/S026021050300007X

Shestack, J. J. (1998). The Philosophic Foundations of Human Rights. Human Rights Quarterly, 20(2), 201-234.

Strauss, A. L. (1987). Qualitative analysis for social scientists. Cambridge: Cambridge University Press.

Strauss, A. L., \& Corbin, J. (1990). Basics of qualitative research : grounded theory procedures and techniques. Newbury Park, Calif.: Sage.

WHO, W. B. a. G. O. (2006). Community Mental Health Development. 


\section{Appendix}

Interviewees

\begin{tabular}{|c|c|c|c|c|c|c|}
\hline Interview 1 & $\begin{array}{l}\text { Nurse and } \\
\text { Health Care } \\
\text { District } \\
\text { Coordinator }\end{array}$ & NGO & female & $\begin{array}{l}40 \\
\sim 40\end{array}$ & Qalqilya & $\begin{array}{l}\text { Working } \\
\text { English }\end{array}$ \\
\hline Interview 2 & $\begin{array}{l}\text { Ex-diplomat \& } \\
\text { General } \\
\text { practitioner }\end{array}$ & NGO & male & $\begin{array}{l}\sim 70 \\
\end{array}$ & Qalqilya & $\begin{array}{l}\text { Excellent } \\
\text { English }\end{array}$ \\
\hline Interview 3 & $\begin{array}{l}\text { Civic engineer } \\
\& \text { hospital } \\
\text { manager }\end{array}$ & NGO & male & $\sim 60$ & Salfit & $\begin{array}{l}\text { Poor } \\
\text { English } \\
\text { (Russian } \\
\text { 2nd } \\
\text { language) }\end{array}$ \\
\hline Interview 4 & Physiotherapist & NGO & male & $\sim 30$ & Nablus & $\begin{array}{l}\text { Poor } \\
\text { English } \\
\text { (Polish 2nd } \\
\text { language) }\end{array}$ \\
\hline Interview 5 & $\begin{array}{l}\text { Health Center } \\
\text { Paediatrician }\end{array}$ & NGO & male & $\sim 40$ & Bethlehem & $\begin{array}{l}\text { Working } \\
\text { English } \\
\text { (Ukrainian } \\
\text { 2nd } \\
\text { language) }\end{array}$ \\
\hline Interview 6 & $\begin{array}{l}\text { PLO Faction } \\
\text { cadre \& NGO } \\
\text { general officer }\end{array}$ & NGO & female & $\sim 50$ & Ramallah & $\begin{array}{l}\text { Excellent } \\
\text { English }\end{array}$ \\
\hline
\end{tabular}




\begin{tabular}{|c|c|c|c|c|c|c|}
\hline Interview 7 & $\begin{array}{l}\text { Health Center } \\
\text { General } \\
\text { Practitioner }\end{array}$ & NGO & male & $\sim 40$ & Hebron & $\begin{array}{l}\text { Working } \\
\text { English }\end{array}$ \\
\hline Interview 8 & $\begin{array}{l}\text { Mobile Clinic } \\
\text { General } \\
\text { Practitioner }\end{array}$ & NGO & male & $\sim 30$ & Jerusalem & $\begin{array}{l}\text { Excellent } \\
\text { English }\end{array}$ \\
\hline Interview 9 & $\begin{array}{l}\text { General } \\
\text { Practitioner }\end{array}$ & $\begin{array}{l}\text { PA \& Palestinian } \\
\text { National Security } \\
\text { Forces }\end{array}$ & male & $\sim 40$ & Bethlehem & $\begin{array}{l}\text { Working } \\
\text { English }\end{array}$ \\
\hline Interview 10 & $\begin{array}{l}\text { Surgeon } \\
\text { Emergency } \\
\text { Care Hospital } \\
\text { NGO }\end{array}$ & NGO & Male & $\sim 40$ & Hebron & $\begin{array}{l}\text { Working } \\
\text { English } \\
\text { (German } \\
\text { 2nd } \\
\text { language) }\end{array}$ \\
\hline Interview 11 & Family doctor & NGO & male & $\sim 50$ & Halhoul & $\begin{array}{l}\text { Working } \\
\text { English } \\
\text { (Romanian } \\
\text { 2nd } \\
\text { language) }\end{array}$ \\
\hline
\end{tabular}

